\title{
The development of lactic acid bacteria and Lactobacillus buchneri and their effects on the fermentation of alfalfa silage
}

\author{
R. J. Schmidt, W. Hu, J. A. Mills, and L. Kung Jr. ${ }^{1}$ \\ Department of Animal and Food Sciences, University of Delaware, Newark 19716-2150
}

\begin{abstract}
This study was conducted to document the development of populations of lactic acid bacteria (LAB) and Lactobacillus buchneri in alfalfa silage treated with various inoculants. Wilted and chopped alfalfa (45\% dry matter) was treated with 1) distilled water (untreated, U), 2) Lactobacillus buchneri $40788\left(4 \times 10^{5}\right.$ $\mathrm{cfu} / \mathrm{g}$; LB), or 3) L. buchneri $40788\left(4 \times 10^{5} \mathrm{cfu} / \mathrm{g}\right)$ and Pediococcus pentosaceus $\left(1 \times 10^{5} \mathrm{cfu} / \mathrm{g}\right.$; LBPP $)$. Forages were packed into triplicate vacuum-sealed, nylonpolyethylene bags per treatment, and ensiled for 2, 5, 45, 90, and $180 \mathrm{~d}$. Viable (cfu) LAB in forage and silage were quantified by traditional plating on selective agar, and numbers of L. buchneri (cfu-equivalent, cfu-E) were quantified by real-time quantitative PCR. Fresh, untreated forage had $5.52 \mathrm{log}$ cfu of LAB/g and $3.79 \mathrm{log}$ cfu-E of L. buchneri/g. After $2 \mathrm{~d}$ of ensiling, numbers of LAB increased to $>8 \mathrm{log} \mathrm{cfu} / \mathrm{g}$ in all silages. In contrast, numbers of L. buchneri in U remained below $4 \mathrm{log}$ cfu-E/g but reached approximately $7 \log \mathrm{cfu}-\mathrm{E} / \mathrm{g}$ in LB and LBPP. From d 5 onward, numbers of L. buchneri in $\mathrm{U}$ remained below $6 \log$ cfu-E/g but approached $9 \log$ cfu-E/g in LB and LBPP. The $\mathrm{pH}$ was lower in LBPP compared with $\mathrm{U}$ and $\mathrm{LB}$ after 2 and $5 \mathrm{~d}$ of ensiling, but $\mathrm{pH}$ was lower for $\mathrm{U}$ compared with $\mathrm{LB}$ and LBPP thereafter. Treatments LB and LBPP had more acetic acid than $\mathrm{U}$ at $45 \mathrm{~d}$ of ensiling, which coincided with detectable amounts of 1,2 propanediol. Inoculation with LBPP resulted in silage with the highest concentration of 1,2 propanediol after $180 \mathrm{~d}$ of ensiling. From d 45 onward, LB and LBPP silages had lower concentrations of residual water-soluble carbohydrates but had higher concentrations of ammonia-N than U. In conclusion, epiphytic L. buchneri can be detected in alfalfa but this population is unable to lead the silage fermentation. In contrast, when L. buchneri was added to silage as an inoculant, the numbers of L. buchneri (cfu-E) increased markedly but did not dictate fermentation until $45 \mathrm{~d}$ of ensiling. These findings help to explain why the re-
\end{abstract}

Received September 10, 2008.

Accepted June 12, 2009.

${ }^{1}$ Corresponding author: lksilage@udel.edu sponse (in increased acetic acid) from the addition of $L$. buchneri in silages is not immediate.

Key words: alfalfa silage, Lactobacillus buchneri, realtime quantitative PCR

\section{INTRODUCTION}

Alfalfa is a forage crop with high nutritive value and is often a major component of diets for high-producing dairy cows (Albrecht and Beauchemin, 2003). However, proper ensiling of this forage crop can be difficult because its high contents of organic acids, salts, proteins, and minerals result in a high buffering capacity (McDonald et al., 1991). Thus, the use of traditional homolactic bacterial inoculants as starters for alfalfa silage has been a recommended practice to ensure rapid fermentation during the early stages of ensiling and to minimize the loss of nutrients and DM (Muck and Kung, 1997; McAllister et al., 1998). However, the use of this type of inoculant may result in decreased aerobic stability because of insufficient production of short-chain fatty acids that are able to inhibit the growth of yeasts and molds (Weinberg et al., 1993). Thus, the heterolactic bacterium Lactobacillus buchneri has been used as an inoculant because it converts moderate amounts of lactic acid to acetic acid under anaerobic conditions (Driehuis et al., 1999). Acetic acid has good antifungal characteristics and has been shown to improve the aerobic stability of a variety of silages (Danner et al., 2003; Holzer et al., 2003). Combining traditional homolactic acid bacteria with L. buchneri has been proposed because inoculants with both types of organisms have the potential to improve the speed of fermentation and enhance the aerobic stability (Driehuis et al., 2001; Weinberg et al., 2002; Adesogan and Salawu, 2004).

Only a few reports document the effects of $L$. buchneri on the fermentation characteristics of alfalfa silage (Kung et al., 2003; Stevenson et al., 2006; Filya et al., 2007; Tyrolova and Vyborna, 2008). In addition, no studies have been conducted to explain why the expected effects of added L. buchneri occur only after 45 to $60 \mathrm{~d}$ of the fermentation process (Kleinschmit and Kung, 2006). Therefore, this experiment was conducted 
to investigate the effects of inoculating alfalfa with $L$. buchneri alone or combined with Pediococcus pentosaceus on the development of populations of lactic acid bacteria (LAB) and L. buchneri in alfalfa silage and their effects on fermentation end-products.

\section{MATERIALS AND METHODS}

\section{Forage and Ensiling Conditions}

Whole-plant alfalfa, cultivar Pioneer 54V46 (Pioneer Hi-Bred International, Des Moines, IA), was mowed at $1 / 10$ bloom, wilted to $45 \% \mathrm{DM}$, and chopped to a theoretical length of $0.95 \mathrm{~cm}$ using a New Holland FP 240 pull-type forage harvester (New Holland, PA) at the University of Delaware Farm in Newark. Forage was divided into three $10-\mathrm{kg}$ piles, which were assigned to one the following treatments: 1) deionized water (300 $\mathrm{mL}$ ), untreated (U), 2) Lactobacillus buchneri NCIMB 40788 (Lallemand Animal Nutrition, Milwaukee, WI) to achieve $4 \times 10^{5} \mathrm{cfu} / \mathrm{g}$ of fresh forage $(\mathbf{L B})$, and 3 ) L. buchneri NCIMB 40788 and Pediococcus pentosaceus NCIMB 12455 to achieve $4 \times 10^{5}$ and $1 \times 10^{5} \mathrm{cfu} / \mathrm{g}$ of fresh forage, respectively (LBPP; Lallemand Animal Nutrition). Microbial inoculants were plated on De Man, Rogosa, and Sharpe (MRS) agar (Oxoid CM0361, Unipath, Basingstoke, UK) beforehand to confirm their viability, and appropriate amounts of the inoculants were used to achieve the desired application rate. Inoculants were dissolved in $300 \mathrm{~mL}$ of deionized water and sprayed uniformly onto the forages under constant mixing. Approximately $400 \mathrm{~g}$ of forage was packed into a nylon-polyethylene bag (25.4 width $\times 35.6 \mathrm{~cm}$ height $)$, vacuumed, and heat sealed (Doug Care Equipment Inc., Springville, CA). Triplicate experimental silos for each treatment were allowed to ensile for $2,5,45,90$, and $180 \mathrm{~d}$ at ambient temperature $\left(20\right.$ to $\left.25^{\circ} \mathrm{C}\right)$ in a closed barn. On each sampling date, silos were opened, their contents were thoroughly mixed, and samples were randomly obtained for the determination of microbial populations and fermentation end-products. Triplicate samples of fresh forage were collected from the initial pile, before its division into $10-\mathrm{kg}$ piles for treatment, for chemical and microbiological analyses.

\section{Chemical and Microbial Analyses}

Dry matter content was determined on fresh forages and silages by drying duplicate samples in a $60^{\circ} \mathrm{C}$ forced-air oven for $48 \mathrm{~h}$. Water extracts were prepared by combining $25 \mathrm{~g}$ of fresh forage or silage with $225 \mathrm{~mL}$ of 25\% Ringer's solution (Oxoid BR0052G) and homogenizing for $1 \mathrm{~min}$, as described by Kung and Ranjit (2001). The $\mathrm{pH}$ of the water extract was measured and a portion of it $(15 \mathrm{~mL})$ was filtered through Whatman 54 filter paper (Clifton, NJ) and acidified with $100 \mu \mathrm{L}$ of $50 \% \mathrm{H}_{2} \mathrm{SO}_{4}$ to reduce the $\mathrm{pH}$ of the extract to $<2$ before freezing $\left(-20^{\circ} \mathrm{C}\right)$. Ammonia- $\mathrm{N}\left(\mathrm{NH}_{3}-\mathrm{N}\right)$ was analyzed by the phenol-hypochlorite procedure (Weatherburn, 1967) and water-soluble carbohydrates were determined as described by Nelson (1944). Water extracts made from silage samples were also analyzed for VFA, 1,2-propanediol, ethanol, and lactic acid with HPLC (Shimadzu SCL-10 AVP) by Dairyland Laboratories (Arcadia, WI). The chromatograph was equipped with a refractive index detector (RID-10A), and a BioRad Aminex ion exclusion HPX-87H $(300 \times 7.8 \mathrm{~mm})$ column was used (Bio-Rad Laboratories, Hercules, CA) at $42^{\circ} \mathrm{C}$. The flow rate of the mobile phase $(0.015 \mathrm{~N}$ $\mathrm{H}_{2} \mathrm{SO}_{4}+0.25 \mathrm{~m} M$ EDTA) was $0.6 \mathrm{~mL} / \mathrm{min}$.

Another portion of each water extract was filtered through a double layer of cheesecloth into 2 sets of sterile tubes for microbial analyses. One set was used for enumeration of viable LAB by pour plating on MRS agar and enumeration of yeasts and molds by pouring on malt extract agar (Oxoid CM0059) that had been acidified to $\mathrm{pH} 3.5$ with $85 \%$ lactic acid $(0.5 \% \mathrm{vol} / \mathrm{vol})$ after autoclaving. Plates were incubated at $32^{\circ} \mathrm{C}$ for 48 $\mathrm{h}$ and numbers of colony-forming units were counted. The second set was frozen $\left(-80^{\circ} \mathrm{C}\right)$ immediately for later extraction of bacterial DNA.

Bacterial DNA was extracted from the water extracts and served as template for real-time quantitative PCR (qPCR) using the primer pair specific for L. buchneri 186-LBF2 (5'-GAAACAGGTGCTAATACCGTATAACAACCA-3') and 316-LBR1 (5'-CGCCTTGGTAGGCCGTTACCTTACCAACA-3'), according to Schmidt et al. (2008). Samples were run in a 7900HT Fast Realtime PCR System (Applied Biosystems, Foster City, $\mathrm{CA}$ ), with the following conditions: $95^{\circ} \mathrm{C}$ for $30 \mathrm{~s}, 61^{\circ} \mathrm{C}$ for $30 \mathrm{~s}$, and $56^{\circ} \mathrm{C}$ for $30 \mathrm{~s}$ for 40 cycles. The reaction mixture contained $12 \mu \mathrm{L}$ of SYBR Green PCR Master Mix (Applied Biosystems), $2 \mu \mathrm{L}$ of DNA of each silage sample, and $100 \mathrm{n} M$ of each primer diluted in $5 \mu \mathrm{L}$ of $\mathrm{H}_{2} \mathrm{O}$. The amplification products were visualized using the software Sequence Detector 1.7 from the ABI Prism 7900 system (Applied Biosystems). The standard curve was constructed using Microsoft Excel 2000 (Microsoft, Redmond, WA) by plotting the number of input cells against the cycle threshold $\left(C_{T}\right)$ value.

For quantification of $L$. buchneri, alfalfa silage (untreated) was sampled from a bag silo at the University of Delaware Dairy (Newark). Lactobacillus buchneri 40788 (Lallemand Animal Nutrition) was applied to this silage at rates of $1 \times 10^{3}$ to $1 \times 10^{8} \mathrm{cfu} / \mathrm{g}$ of silage. Isolation of DNA, PCR, and the visualization of the amplified product were performed on water extracts from the silage as described previously. Numbers of 
Table 1. The DM content of alfalfa during ensiling

\begin{tabular}{lcccc}
\hline & \multicolumn{3}{c}{ Treatment $^{1}$} \\
\cline { 2 - 4 } Time point & $\mathrm{U}$ & LB & LBPP & SE \\
\hline $0 \mathrm{~d}$ & 45.35 & 45.35 & 45.35 & $\mathrm{ND}^{2}$ \\
$2 \mathrm{~d}$ & $41.75^{\mathrm{b}}$ & $43.44^{\mathrm{a}}$ & $42.27^{\mathrm{b}}$ & 0.17 \\
$5 \mathrm{~d}$ & 44.19 & 43.34 & 40.32 & 1.23 \\
$45 \mathrm{~d}$ & $44.25^{\mathrm{a}}$ & $42.63^{\mathrm{ab}}$ & $41.34^{\mathrm{b}}$ & 0.75 \\
$90 \mathrm{~d}$ & $43.77^{\mathrm{a}}$ & $42.82^{\mathrm{a}}$ & $41.72^{\mathrm{b}}$ & 0.30 \\
$180 \mathrm{~d}$ & $45.62^{\mathrm{a}}$ & $42.22^{\mathrm{b}}$ & $41.57^{\mathrm{b}}$ & 0.37 \\
\hline
\end{tabular}

${ }^{\mathrm{a}, \mathrm{b}}$ Values with unlike superscript letters within a day differ $(P<$ $0.05)$.

${ }^{1} \mathrm{U}=$ untreated silage; $\mathrm{LB}=$ Lactobacillus buchneri $\left(4 \times 10^{5} \mathrm{cfu} / \mathrm{g}\right.$ of wet forage); $\mathrm{LBPP}=$ L. buchneri and Pediococcus pentosaceus $\left(4 \times 10^{5}\right.$ and $1 \times 10^{5} \mathrm{cfu} / \mathrm{g}$ of wet forage, respectively).

${ }^{2} \mathrm{ND}=$ not determined

L. buchneri are presented as cfu-equivalents (cfu-E) because detected bacterial DNA can come from viable and dead bacteria.

Aerobic stability was not measured in this study because there were no detectable yeasts after $5 \mathrm{~d}$ of ensiling. The recovery of the DM was not measured because of the use of small-scale silos.

\section{Statistical Analysis}

All microbial data were transformed to log units and are presented on a wet weight basis. Chemical data are presented on a DM basis. Data from each day was analyzed separately as a completely randomized design by using the GLM procedure of SAS (SAS Institute, 1998). Tukey's test (Snedecor and Cochran, 1980) was used to test treatments, and significance was declared at $P<0.05$.

\section{RESULTS AND DISCUSSION}

The DM content of silages is shown in Table 1 and although there were several significant differences among treatments, these differences were small and not biologically significant.

The population of viable $\mathrm{LAB}$ in untreated alfalfa increased rapidly from $5.52 \mathrm{log} \mathrm{cfu} / \mathrm{g}$ in fresh forage to more than $9 \mathrm{log} \mathrm{cfu} / \mathrm{g}$ of silage by d 2 of fermentation (Figure 1). Similar results in alfalfa silage have been reported by Kung et al. (2003). Subsequently, the population of LAB peaked after $5 \mathrm{~d}$, declined slowly at 45 and $90 \mathrm{~d}$, and was lowest $(5.2 \mathrm{log} \mathrm{cfu} / \mathrm{g}$ ) after $180 \mathrm{~d}$. The decrease in LAB over time was expected because low $\mathrm{pH}$ and lack of fermentable substrates result in death of bacteria (McDonald et al., 1991; Pahlow et al., 2003).

To our best knowledge, this study was the first to use a real-time qPCR technique to quantify the growth of
L. buchneri in alfalfa silage by creating a standard with pure cultures of L. buchneri grown on agar plates and applied to alfalfa silage. It is important to note that the cfu-E detected by real-time qPCR is not equal to a culturable, viable plate count on MRS agar because DNA from both live and dead L. buchneri contributes to the quantification. Stevenson et al. (2006) reported a decline in the presumptive population of L. buchneri within the first $48 \mathrm{~h}$ of fermentation in alfalfa silages that were inoculated with that bacterium but this was because they presented their data as a percentage of total bacterial DNA present in the silage. Because the primer pair utilized in this assay is not strain specific, naturally low levels of $L$. buchneri were found in fresh alfalfa (Figure 2). Using classic microbiological methods, Torriani et al. (1992) isolated LAB from alfalfa and over $20 \%$ of the isolates were classified as L. buchneri. In our study, the natural population of L. buchneri was never more than $5.52 \mathrm{log} \mathrm{cfu}-\mathrm{E} / \mathrm{g}$ of silage and it was not able to dominate the fermentation process. The population of $L$. buchneri cfu-E increased markedly after $2 \mathrm{~d}$ of ensiling in both inoculated silages and was almost $3 \mathrm{log}$ higher compared with untreated silage and continued to increase in these silages after $5 \mathrm{~d}$ of ensiling. At 45 , 90, and $180 \mathrm{~d}$ of ensiling L. buchneri cfu-E appeared to be the predominant bacterium in inoculated silages based on their fermentation profiles. The slow development of added L. buchneri most likely explains why the effects of this organism in silage are evident during the storage phase of ensiling (approximately $60 \mathrm{~d}$ ), which is in agreement with the findings of Oude Elferink et al. (2001), in which the metabolism of L. buchneri in pure culture was studied.

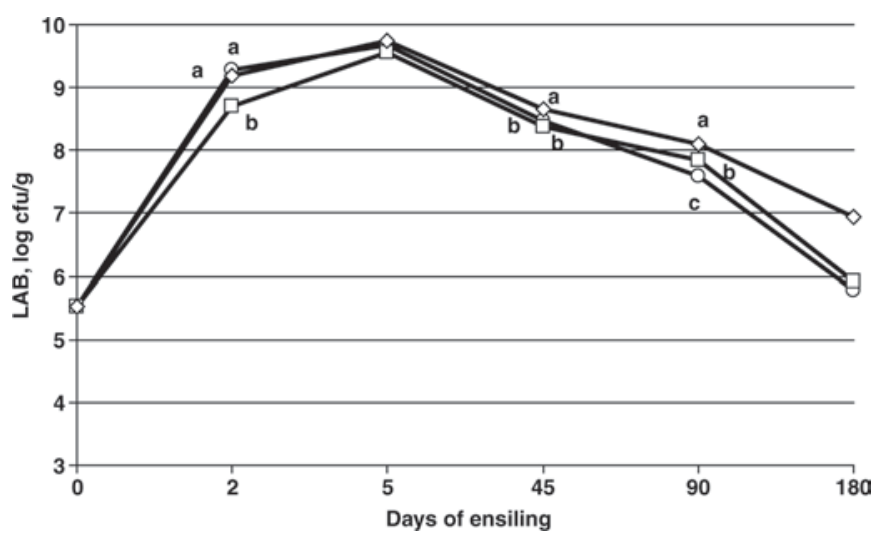

Figure 1. The population of lactic acid bacteria (LAB) in alfalfa silages during ensiling. $\mathrm{U}=$ untreated silage $(\mathrm{O}): \mathrm{LB}=$ Lactobacillus buchneri $\left(4 \times 10^{5} \mathrm{cfu} / \mathrm{g}\right.$ of wet forage; $\left.\square\right)$; LBPP $=$ L. buchneri and Pediococcus pentosaceus $\left(4 \times 10^{5}\right.$ and $1 \times 10^{5} \mathrm{cfu} / \mathrm{g}$ of wet forage, respectively; $\diamond)$. ${ }^{\mathrm{a}-\mathrm{c}}$ Data points for specific days with unlike letters differ $(P<0.05)$. 


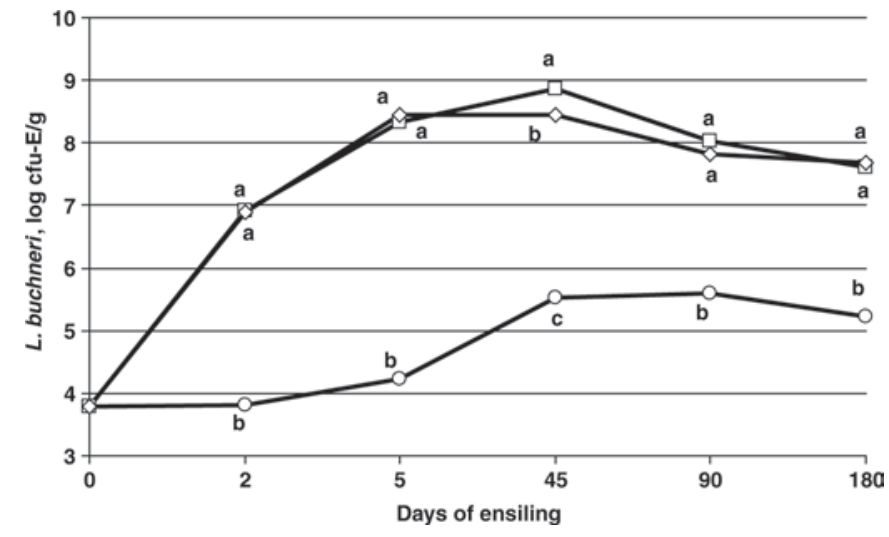

Figure 2. The population of Lactobacillus buchneri in alfalfa silages during ensiling. $\mathrm{U}=$ untreated silage $(\mathrm{O})$; $\mathrm{LB}=$ Lactobacillus buchneri $\left(4 \times 10^{5} \mathrm{cfu} / \mathrm{g}\right.$ of wet forage; $\left.\square\right) ; \mathrm{LBPP}=$ L. buchneri and Pediococcus pentosaceus $\left(4 \times 10^{5}\right.$ and $1 \times 10^{5} \mathrm{cfu} / \mathrm{g}$ of wet forage, respectively; $\left.\diamond\right)$.

${ }^{\mathrm{a}-\mathrm{c}}$ Data points for specific days with unlike letters differ $(P<0.05)$.

The effect of inoculation on silage $\mathrm{pH}$ is shown in Figure 3. Silage treated with LBPP had the fastest decrease in $\mathrm{pH}$ after 2 and $5 \mathrm{~d}$, suggesting dominance from the addition of $P$. pentosaceus. In contrast, inoculation with $\mathrm{LB}$ resulted in the slowest decrease in $\mathrm{pH}$ compared with that of other silages, which agrees with previous findings with alfalfa (Kung et al., 2003). From d 45 on, silage $\mathrm{pH}$ was higher for both inoculated silages when compared with untreated silage. The concentration of lactic acid increased rapidly in all treatments (Figure 4) and was lowest for LB compared with LBPP and U at 2 d. Differences in concentrations of acetic acid (Figure 5) and 1,2 propanediol (Figure 6) between untreated and inoculated silages became more evident starting at $45 \mathrm{~d}$ of ensiling and continued through $180 \mathrm{~d}$. These compounds are characteristic of silages inoculated with

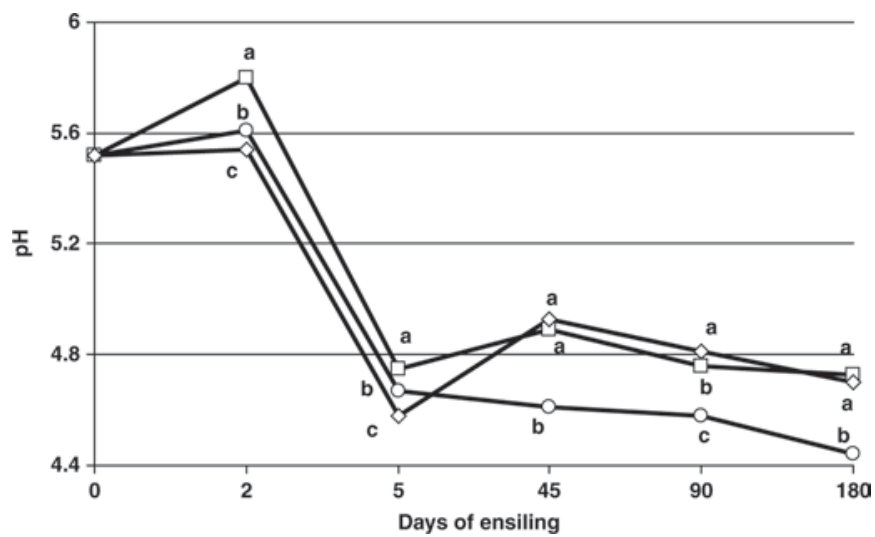

Figure 3. The $\mathrm{pH}$ of alfalfa silages during ensiling. $\mathrm{U}=$ untreated silage $(\bigcirc)$; LB $=$ Lactobacillus buchneri $\left(4 \times 10^{5} \mathrm{cfu} / \mathrm{g}\right.$ of wet forage; $\square) ; \mathrm{LBPP}=L$. buchneri and Pediococcus pentosaceus $\left(4 \times 10^{5}\right.$ and 1 $\times 10^{5} \mathrm{cfu} / \mathrm{g}$ of wet forage, respectively; $\left.\diamond\right)$. ${ }^{\mathrm{a}-\mathrm{c}}$ Data points for specific days with unlike letters differ $(P<0.05)$.

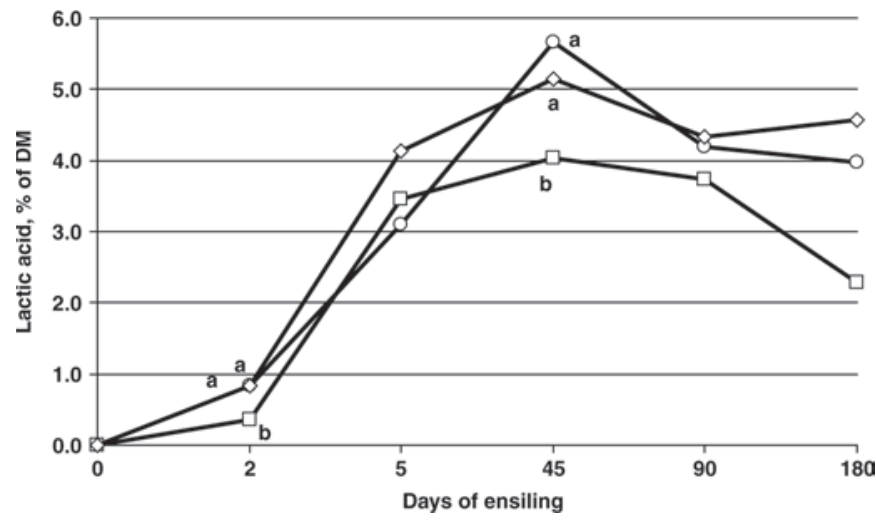

Figure 4. The concentration of lactic acid in alfalfa silages during ensiling. $\mathrm{U}=$ untreated silage $(\bigcirc) ; \mathrm{LB}=$ Lactobacillus buchneri $(4$ $\times 10^{5} \mathrm{cfu} / \mathrm{g}$ of wet forage; $\left.\square\right) ; \mathrm{LBPP}=$ L. buchneri and Pediococcus pentosaceus $\left(4 \times 10^{5}\right.$ and $1 \times 10^{5} \mathrm{cfu} / \mathrm{g}$ of wet forage, respectively; $\left.\diamond\right)$. ${ }^{a, b}$ Data points for specific days with unlike letters differ $(P<0.05)$.

L. buchneri, although the increase in their numbers detected by qPCR was evident after just $2 \mathrm{~d}$. During the initial phase of active fermentation, L. buchneri generates energy by fermenting simple sugars similar to other heterolactic acid bacteria, which results in an increase in their numbers. In the subsequent phase of ensiling, $L$. buchneri is induced by the low $\mathrm{pH}$ to ferment moderate amounts of lactic acid under anaerobic conditions, but this is a slow process and yields low amounts of energy (Oude Elferink et al., 2001); therefore, the enhancement in the concentration of the end-products from this pathway - acetic acid and 1,2-propanediol-has usually not been observed until approximately 45 to $60 \mathrm{~d}$ of storage (Driehuis et al., 1999; Kleinschmit and Kung, 2006). The present data on the concentrations of acetic acid and 1,2-propanediol in inoculated silages support

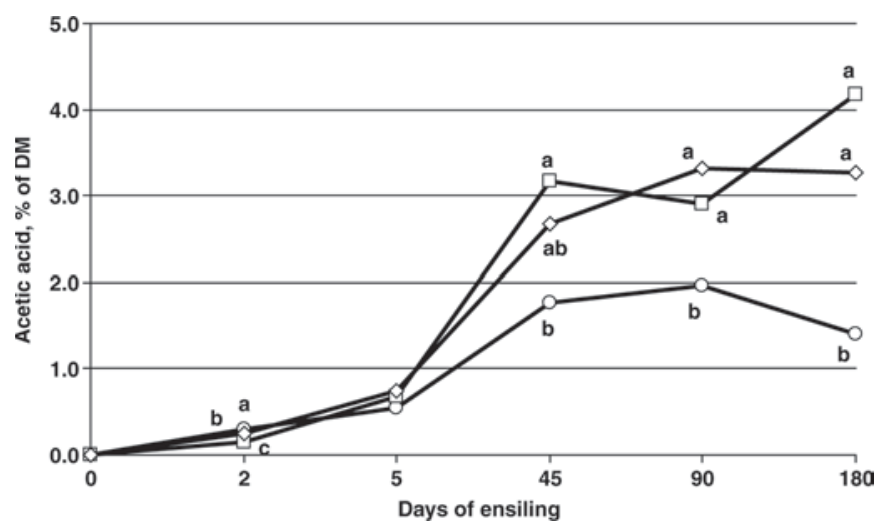

Figure 5. The concentration of acetic acid in alfalfa silages during ensiling. $\mathrm{U}=$ untreated silage $(\bigcirc)$; $\mathrm{LB}=$ Lactobacillus buchneri $(4$ $\times 10^{5} \mathrm{cfu} / \mathrm{g}$ of wet forage; $\left.\square\right)$; LBPP $=$ L. buchneri and Pediococcus pentosaceus $\left(4 \times 10^{5}\right.$ and $1 \times 10^{5} \mathrm{cfu} / \mathrm{g}$ of wet forage, respectively; $\left.\diamond\right)$. ${ }^{\mathrm{a}-\mathrm{C}}$ Data points for specific days with unlike letters differ $(P<0.05)$. 


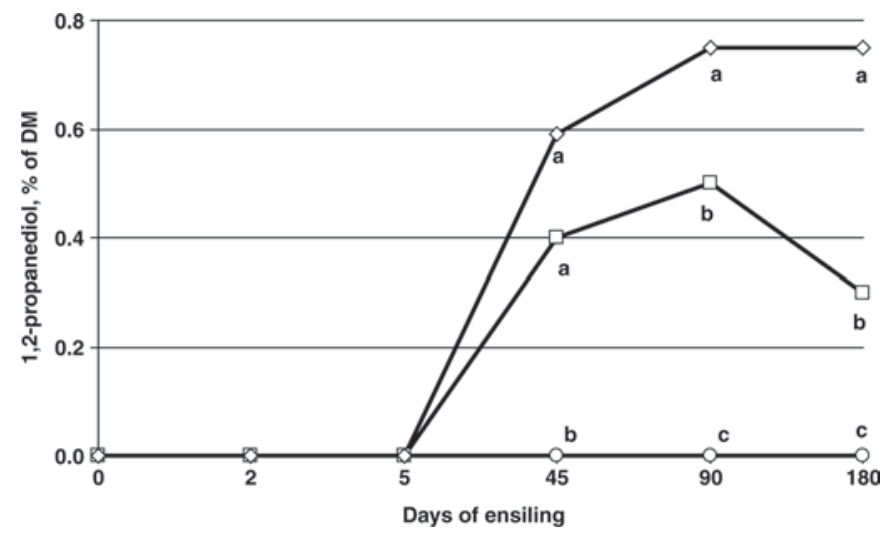

Figure 6. The concentration of 1,2-propanediol in alfalfa silages during ensiling. $\mathrm{U}=$ untreated silage $(\mathrm{O}) ; \mathrm{LB}=$ Lactobacillus buchneri $\left(4 \times 10^{5} \mathrm{cfu} / \mathrm{g}\right.$ of wet forage; $\left.\square\right) ; \mathrm{LBPP}=$ L. buchneri and Pediococcus pentosaceus $\left(4 \times 10^{5}\right.$ and $1 \times 10^{5} \mathrm{cfu} / \mathrm{g}$ of wet forage, respectively; $\left.\diamond\right)$.

${ }^{\mathrm{a}-\mathrm{c}}$ Data points for specific days with unlike letters differ $(P<0.05)$.

the existence of high populations of L. buchneri in those silages. For unknown reasons, the concentration of 1,2 propanediol, which is an end-product formed during the anaerobic conversion of lactic acid to acetic acid by L. buchneri (Oude Elferink et al., 2001), was greater from $45 \mathrm{~d}$ onward for LBPP compared with LB. Some naturally occurring organisms in silage can convert 1,2-propanediol to propanol and then to propionic acid (Krooneman et al., 2002). We did not detect propionic acid in our silages.

Concentrations of water-soluble carbohydrates (Figure 7) decreased after $2 \mathrm{~d}$ of ensiling, and differences among treatments generally reflected the production of acids. Inoculation resulted in some differences in the concentration of ethanol (data not shown), because ab-

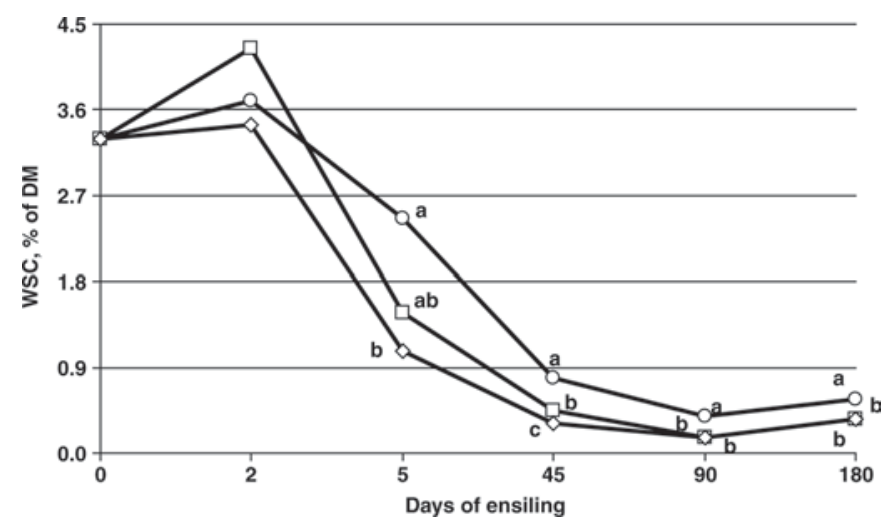

Figure 7. The concentration of water-soluble carbohydrates (WSC) in alfalfa silages during ensiling. $\mathrm{U}=$ untreated silage $(\mathrm{O})$; LB $=$ Lactobacillus buchneri $\left(4 \times 10^{5} \mathrm{cfu} / \mathrm{g}\right.$ of wet forage; $\left.\square\right)$; LBPP $=L$. buchneri and Pediococcus pentosaceus $\left(4 \times 10^{5}\right.$ and $1 \times 10^{5} \mathrm{cfu} / \mathrm{g}$ of wet forage, respectively; $\diamond) .{ }^{a-c}$ Data points for specific days with unlike letters differ $(P<0.05)$.

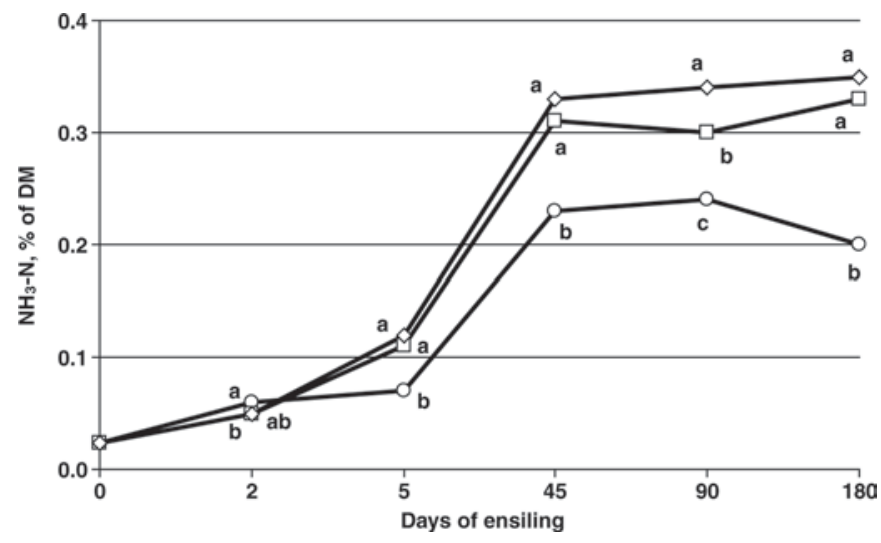

Figure 8. The concentration of ammonia- $\mathrm{N}$ in alfalfa silages during ensiling. $\mathrm{U}=$ untreated silage $(\mathrm{O}): \mathrm{LB}=$ Lactobacillus buchneri $(4$ $\times 10^{5} \mathrm{cfu} / \mathrm{g}$ of wet forage; $\left.\square\right) ; \mathrm{LBPP}=L$. buchneri and Pediococcus pentosaceus $\left(4 \times 10^{5}\right.$ and $1 \times 10^{5} \mathrm{cfu} / \mathrm{g}$ of wet forage, respectively; $\left.\diamond\right)$.

${ }^{\mathrm{a}-\mathrm{c}}$ Data points for specific days with unlike letters differ $(P<0.05)$.

solute concentrations were low $(<0.30 \%)$ in all silages, especially during the later stages of storage. Inoculated silages had higher concentrations of $\mathrm{NH}_{3}-\mathrm{N}$ compared with control silage at 5,45,90, and $180 \mathrm{~d}$ of ensiling (Figure 8) and thus more deamination occurred in treated silages. Although adding classical homolactic acid bacteria to alfalfa has often resulted in a decrease in $\mathrm{NH}_{3}-\mathrm{N}$ (Muck, 1989), addition of the homolactic bacterium $P$. pentosaceus with L. buchneri in the current study could not prevent the increase apparently brought about by L. buchneri. Some previous studies have also reported that addition of $L$. buchneri increased $\mathrm{NH}_{3} \mathrm{~N}$ in alfalfa (Kung et al., 2003), grass (Driehuis et al., 2001), and corn and sorghum (Filya, 2003).

Yeasts and molds were only detected in silages through d 5 of ensiling (Table 2) and there were no differences among treatments. Low numbers of yeasts and molds in alfalfa silage is a common finding (Hoffman et al., 1998; Kung et al., 2003).

\section{CONCLUSIONS}

This study showed that the natural population of $L$. buchneri in alfalfa silage is unable to dominate the early fermentation process. However, inoculating silages with L. buchneri resulted in silages with higher levels of acetic acid and 1,2-propanediol. Accumulation of these end-products coincided with the slow but steady development of populations of L. buchneri in inoculated silages at $45 \mathrm{~d}$ of ensiling. The slow growth of added $L$. buchneri explains, in part, why its effects on fermentation are detected later in the ensiling process. Adding P. pentosaceus with L. buchneri resulted in a faster rate of fermentation during the very early stages of ensiling. 
Table 2. The population of yeasts and molds (log cfu/g, wet basis) in alfalfa silages after 2 and $5 \mathrm{~d}$ of ensiling with 1 of 3 treatments $^{1}$

\begin{tabular}{|c|c|c|c|c|c|c|c|c|}
\hline \multirow[b]{2}{*}{ Item } & \multicolumn{4}{|c|}{ Day 2} & \multicolumn{4}{|c|}{ Day 5} \\
\hline & $\mathrm{U}$ & LB & LBPP & $\mathrm{SE}$ & $\mathrm{U}$ & LB & LBPP & $\mathrm{SE}$ \\
\hline Yeasts & 4.30 & 2.71 & 5.09 & 0.82 & 3.71 & 3.54 & 3.67 & 0.25 \\
\hline Molds & 3.34 & 3.58 & 4.20 & 0.28 & 3.14 & 3.04 & 3.37 & 0.26 \\
\hline
\end{tabular}

\section{ACKNOWLEDGMENTS}

The authors thank Candice Klingerman and Erin McDonell of the University of Delaware for assistance in the analytical analysis. We also thank Jon Hummel and the farm crew of the University of Delaware for planting and harvesting of crop. This study was partially funded by Lallemand Animal Nutrition (Milwaukee, WI).

\section{REFERENCES}

Adesogan, A. T., and M. B. Salawu. 2004. Effect of applying formic acid, heterolactic bacteria or homolactic and heterolactic bacteria on the fermentation of bi-crops of peas and wheat. J. Sci. Food Agric. 84:983-992.

Albrecht, K. A., and K. A. Beauchemin. 2003. Alfalfa and other perennial legume silage. Pages 633-665 in Silage Science and Technology. D. R. Buxton, R. E. Muck, and J. H. Harrison, ed. American Society of Agronomy Inc., Crop Science Society of America Inc., Soil Science Society of America Inc. Publications, Madison, WI.

Danner, H., M. Holzer, E. Mayrhuber, and R. Braun. 2003. Acetic acid increases stability of silage under aerobic conditions. Appl. Environ. Microbiol. 69:562-567.

Driehuis, F., S. J. W. H. Oude Elferink, and S. F. Spoelstra. 1999. Anaerobic lactic acid degradation during ensiling of whole crop maize inoculated with Lactobacillus buchneri inhibits yeast growth and improves aerobic stability. J. Appl. Microbiol. 87:583-594.

Driehuis, F., S. J. W. H. Oude Elferink, and P. G. Van Wikselaar. 2001. Fermentation characteristics and aerobic stability of grass silage inoculated with Lactobacillus buchneri, with or without homofermentative lactic acid bacteria. Grass Forage Sci. 56:330343.

Filya, I. 2003. The effect of Lactobacillus buchneri and Lactobacillus plantarum on the fermentation, aerobic stability, and ruminal degradability of low dry matter corn and sorghum silages. J. Dairy Sci. 86:3575-3581.

Filya, I., R. E. Muck, and F. E. Contreras-Govea. 2007. Inoculant effects on alfalfa silage: Fermentation profile products and nutritive value. J. Dairy Sci. 90:5108-5114.

Hoffman, P. C., D. K. Combs, and M. D. Casler. 1998. Performance of lactating dairy cows fed alfalfa silage or perennial ryegrass silage. J. Dairy Sci. 81:162-168.

Holzer, M., E. Mayhuber, H. Danner, and R. Braun. 2003. The role of Lactobacillus buchneri in forage preservation. Trends Biotechnol. 21:282-287.

Kleinschmit, D. H., and L. Kung Jr.. 2006. The effects of Lactobacillus buchneri 40788 and Pediococcus pentosaceus R1094 on the fermentation of corn silage. J. Dairy Sci. 89:3999-4004.

Krooneman, J., F. Faber, A. C. Alderkamp, S. J. H. W. Oude Elferink, F. Driehuis, I. Cleenwerk, J. Swings, and J. C. Gottschal. 2002. Lactobacillus diolivorans sp. nov., a 1,2-propanediol-degrading bacterium isolated from aerobically stable maize silage. Int. J. Syst. Evol. Microbiol. 52:639-646.
Kung, L. Jr., and N. K. Ranjit. 2001. The effect of Lactobacillus buchneri and other additives on the fermentation and aerobic stability of barley silage. J. Dairy Sci. 84:1149-1155.

Kung, L. Jr., C. C. Taylor, M. P. Lynch, and J. M. Neylon. 2003. The effect of treating alfalfa with Lactobacillus buchneri 40788 on silage fermentation, aerobic stability, and nutritive value for lactating dairy cows. J. Dairy Sci. 86:336-343.

McAllister, T. A., R. Feniuk, Z. Mir, P. Mir, L. B. Seling, and K.J. Cheng. 1998. Inoculants for alfalfa silage: Effects on aerobic stability, digestibility and the growth performance of feedlot steers. Livest. Prod. Sci. 53:171-181.

McDonald, P., A. R. Henderson, and S. J. E. Heron. 1991. The biochemistry of silage. Chalcombe Publ., Marlow, UK.

Muck, R. E. 1989. Effects of inoculation level on alfalfa silage quality. Trans. ASAE 32:1153-1158.

Muck, R. E., and L. Kung Jr. 1997. Effects of silage additives on ensiling. Pages 187-199 in Silage: Field to Feedbunk. NRAES-99. Northeast Regional Agricultural Engineering Service, Ithaca, NY.

Nelson, N. 1944. A photometric adaptation of the Somogyi method for the determination of glucose. J. Biol. Chem. 153:375-380.

Oude Elferink, S. J. W. H., J. Krooneman, J. C. Gottschal, S. F. Spoestra, F. Faber, and F. Driehuis. 2001. Anaerobic conversion of lactic acid to acetic acid and 1,2-propanediol by Lactobacillus buchneri. Appl. Environ. Microbiol. 67:125-132.

Pahlow, G., R. E. Muck, F. Driehuis, S. J. W. H. Oude Elferink, and S. F. Spoelstra. 2003. Microbiology of ensiling. Pages 31-34 in: Silage Science and Technology. Agron. Monogr. 42. D. R. Buxton, R. E. Muck, and J. H. Harrison, ed. American Society of Agronomy Inc., Crop Science Society of America Inc., Soil Science Society of America Inc. Publications, Madison, WI.

SAS Institute. 1998. SAS User's Guide: Statistics. Version 7 ed. SAS Inst., Inc., Cary, NC.

Schmidt, R. J., M. G. Emara, and L. Kung Jr.. 2008. The use of a quantitative real-time polymerase chain reaction assay for identification and enumeration of Lactobacillus buchneri in silages. J. Appl. Microbiol. 105:920-929.

Snedecor, G. W., and W. G. Cochran. 1980. Statistical Methods. 6th ed. Iowa State Univ. Press, Ames.

Stevenson, D. M., R. E. Muck, K. J. Shinners, and P. J. Weimer. 2006. Use of real time PCR to determine profiles of individual species of lactic acid bacteria in alfalfa silage and stored corn stover. Appl. Microbiol. Biotechnol. 71:329-338.

Torriani, S., M. Palummeri, L. Coscia, M. Baetens, and F. Dellaglio. 1992. Detection and characterization of epiphytic lactic acid bacteria on growing plants of maize and lucerne. Ann. Microbiol. Enzimol. 42:49-59.

Tyrolova, Y., and A. Vyborna. 2008. Effect of the stage of maturity on the leaf percentage of Lucerne and the effect of additives on silage characteristics. Czech J. Anim. Sci. 53:330-335.

Weatherburn, M. W. 1967. Phenol-hypochlorite reaction for determinations of ammonia. Anal. Chem. 39:971-974.

Weinberg, Z. G., G. Ashbell, Y. Hen, and A. Azrieli. 1993. The effect of applying lactic acid bacteria on the aerobic stability of silages. J. Appl. Bacteriol. 75:512-518.

Weinberg, Z. G., G. Ashbell, Y. Hen, A. Azrieli, G. Szakacs, and I. Filya. 2002. Ensiling whole-crop wheat and corn in large containers with Lactobacillus plantarum and Lactobacillus buchneri. J. Ind. Microbiol. Biotechnol. 28:7-11. 